constant temperature and X-ray rooms, animal rooms, staff common room, workshop, store room, lavatories, and also an unloading room in which packages can be transferred from a lorry directly into the electric lift which serves all floors. A caretaker's house of five rooms occupies the west end of the floor. In the attic, which runs the whole length of the building, are the aquarium, aviary, terrarium, and store room.

In the entrance hall are panels framed in oak with the names of students who have taken higher degrees whilst guests of the Department. At the top of the panels there is carved "De fructibus suis agnoscebantur." Under this honours panel there is an oak table and stools.

The heating of the Department is by low pressure steam.

In addition to this main block there lies, to the south-west, a sheep building provided by the Empire Marketing Board and equipped with operating theatre, sterilising and instrument rooms, food stores, and sheep pens. To the north-west there is a large brick intensive poultry house accommodating 200 birds. To the north there are the large pig building and goat house provided by the Department of Agriculture for Scotland. Several wooden buildings house the rabbit, rat, and mouse colonies, whilst others accommodate the monkeys and fowls.

The new building was officially opened on Monday, June 30, by the first chairman of the Joint Committee on Research in Animal Breeding, Sir Edward SharpeySchafer, president of the Royal Society of Edinburgh. At the opening ceremony, the degree of Doctor of Laws, honoris causa, was conferred by the ViceChancellor, Sir Thomas Holland, upon Mr. T. B. Macaulay, the president of the Sun Life Assurance Company of Canada, a Canadian with strong Scottish connexions, who has shown considerable interest in the affairs of the department and has endowed therein a lectureship and several assistantships.

\title{
The Museums Association and Museum Extension.
}

$\mathrm{T}$ forty-first annual conference of the Museums Association, which met at Cardiff, on June 23-27, by invitation of the Lord Mayor and Corporation and of the National Museum of Wales, was successful in all aspects. It was attended by more than 230 delegates and other members from all parts of the British Isles, as well as from the United States, Germany, and Sweden; these represented all classes of museums, from the great national institutions to the smallest village museums. The last statement strikes the main note of the conference : the knitting up of the museum service of the country and its extension to the remoter districts, a subject on which valuable discussions took place. The National Museum of Wales has itself set a brilliant example of such work, and, with its beautiful building and admirable arrangement, formed an inspiring focus of the proceedings. The guidance of its officers, the hospitality of the Lord Mayor, of the Mayors of Newport and Merthyr Tydfil, of Lord Treowen, and of numerous friends combined with the fine weather and the charm of the surrounding country to make the stay of the visitors as delightful as it was profitable.

The president, Sir Henry Miers, referred in his address first to the Report of the Royal Commission on National Museums and discussed the suggestions which it made for the co-operation of the Museums Association. In the event of a Standing Commission being appointed, it was hoped that the Association would have official representation on it. The proposed enlargement of the Circulation Department to include all suitable classes of museum material would be an important factor in co-ordinating museums, while the extension of the method of affiliation adopted by the National Museum of Wales should assist in their co-operation. Plans for a training course, as desired by the Royal Commission, were already published in the Museums Journal, and it was hoped that municipal bodies would assist their junior officers to attend. The scheme for a National Open-Air Folk Museum was making good progress in the hands of a strong committee.

Turning to the proposals of the Carnegie Trustees, the president said that the advice of the Association would be asked when grants were allotted to museums; it was necessary that museums should fulfil the conditions laid down in his own published report to the trustees; meanwhile museums might consider plans of work to which they might apply any possible grant. For the Association to perform the duties requested of it by the Royal Commission and by the Carnegie
Trustees, it was necessary that it should acquire a legal status ; as a first step it was proposed " that the Museums Association be converted into a Company, limited by guarantee and not having a share capital." This, with the consequent changes in the constitution of the Association, was accepted by the subsequent general meeting, which fixed the amount of the guarantee at $10 \mathrm{~s}$. for each member.

Finally, the president repeated some of his previous recommendations, as that the museums of a district should combine to hold a district loan exhibition; that museums should distribute their surplus material, and render their research material more available for workers; and that they should prepare educational exhibits for circulation to schools and to towns or villages unprovided with a museum.

This last was the subject of two papers by Dr. T. W. Woodhead, of Huddersfield, and Mr. W. C. Sprunt, of Batley, who described the kind of exhibits sent out, the mode of packing, and the system of distribution. It was pointed out in the discussion that museums had been doing this work long before the libraries took it up. There has, however, been no systematic attempt to provide branch museums in the villages for those of more mature years, at least so far as Great Britain is concerned. The numerous rural museums in Sweden, of which Dr. Klein of the Northern Museum gave an entertaining account, are independent folk museums of high value in promoting local patriotism but not educational in the formal sense. The same may be said of the Heimatmuseen, now springing up all over Germany, of which the ideals were eloquently expounded by Dr. Otto Lehmann.

The more usual type of small museum was in the minds of Dr. F. J. North and Mr. H. A. Hyde, who showed what it might usefully exhibit in geology and botany respectively. The affiliation of such museums to a central museum was discussed by Dr. Cyril Fox, from his experience as director of the National Museum of Wales. He had found the chief difficulty in any scheme to be the lack of a permanent and competent curator ; the parent museum could neither lend nor give material to a museum that was unable to care for it.

The Carnegie Trustees had sent their assistant secretary, Mr. A. B. Hyslop, to glean suggestions that might help towards some scheme of museum extension to rural areas. They were hoping to take counsel with the County Directors of Education and with the Circulation Department of the Victoria and Albert Museum ; but it is clear that the burden of the work

No. 3167, VoL. 126] 
must fall on local museum curators, just as that of library extension has been borne by public librarians. There can be no question of the willingness of curators to help ; many of them have been doing the work for years, sometimes with the co-operation or at least the sanction of the educational authorities, sometimes in spite of their lethargy, and out of their own slender resources. If the Carnegie Trustees can induce the educational authorities in any one area to co-operate whole-heartedly with the museum curators, an example will speedily be set which the rest of the country will feel bound to follow. It is, however, to be hoped that the benefits will not be confined to schoolchildren, but that the needs and interests of others, especially the adolescent, will be kept prominently in view.

\section{International Congress of Actuaries.}

$\mathrm{T}^{\mathrm{H}}$ $\mathrm{E}$ ninth international congress of actuaries was held at Stockholm on June 16-20 and was largely attended by actuaries from all over the world. The arrangements were made by the Swedish Society of Actuaries and the Swedish Association of Assurance, and the presidents for the time being of those bodies (Dr. Phragmén and Mr. Sven Palme) being the joint presidents of the Congress. Several subjects were chosen for discussion and the papers submitted were printed in English, French, or German, at the author's choice, with abstracts in the other languages. Each subject was then introduced by a short speech by a Scandinavian actuary and a general discussion followed.

One of the subjects of most general interest discussed at the Congress was the treatment of sickness and disability in social insurance or in connexion with pensions or life assurance, and it was apparent that the granting of these benefits on invalidity has led to far heavier rates of invalidity than those prevailing prior to the institution of the schemes. This effect is noticeable whether we look at State or private schemes of insurance. Attention had already been directed to the point in England, and most other countries are having to face the same difficulties. It is probably inevitable that, even if definite malingering be excluded, some such result should appear, but it makes the actual expense of such schemes greater than the estimated expense on the basis of older experience acquired in different conditions. The subjects of general scientific rather than professional interest were the statistical evidence available with regard to the influence of tuberculosis on mortality and the application of modern statistical treatment to problems of risk. In connexion with the latter, non-Scandinavian actuaries had the opportunity of considering Lundberg's interesting new theory of risk, and it was satisfactory to find a paper giving a definite warning against the assumption of the normal curve, in connexion with the discussion of deviations in assurance work, when Poisson's law would be a proper assumption.

On the strictly actuarial side, the fair distribution of surplus was discussed by many actuaries in written and verbal communications, while on the practical life assurance side the comparison of 'participating with 'non-participating' assurances and the relative advantages of assurances that merely cover risk, as compared with those that are largely for purposes of saving, evoked a good discussion.

The meetings were held in the new concert hall and the arrangements were excellent. The interpreting was remarkably good; thanks partly to the choice of linguists with a first-class knowledge of the subjects under discussion.

The Congress was graciously received at the Royal Palace for tea by H.M. the King, and the Crown Prince, as Président d'honneur, attended and spoke at the opening meeting. It only remains to record the generous hospitality of our Swedish hosts to the members of the Congress and their wives : it would be hard to imagine greater kindness.

W. P. E.

\section{Rayleigh Collection at the Science Museum.}

$\triangle$ MONG recent additions to the Science Museum, A South Kensington, is a most interesting collection of apparatus used by the late Lord Rayleigh in the course of his scientific research. On the occasion of the unfortunate fire, last year, at Lord Rayleigh's home at Terling, Essex, a considerable quantity of apparatus was destroyed, but the historical apparatus was fortunately undamaged and the bulk of it has been generously given by the present Lord Rayleigh to the Science Museum, where it should prove a continual source of interest and inspiration to professional and amateurscientific workers alike. It is scarcely necessary to remind readers of NATURE of the extent and importance of the late Lord Rayleigh's contributions to science. During a period of more than fifty years he published no fewer than 446 papers, every one of which made a distinct addition to our knowledge of the subject and was characterised by that lucidity and elegance of expression for which its author was renowned.

On viewing this collection, one is struck very forcibly - as were visitors to the laboratory at Terling-by the extraordinary simplicity of the bulk of the apparatus. The ability to attain results of the highest accuracy and importance by the aid of odd bits of wood, glass tubing, wire, and sealing-wax was undoubtedly bound up with Rayleigh's unerring instinct in discriminating between the essential and the non-essential. It is doubtless true that some branches of modern physical research cannot profitably be pursued without the use of expensive apparatus. At the same time, many workers who are apt to grow despondent after a perusal of the price-lists of the scientific instrument makers should find a tonic in the Rayleigh collection, which also serves as a salutary reminder that the man is more important than his tools.

The present collection is thoroughly representative of the vast field which Lord Rayleigh covered, and is exhibited in six cases, two dealing with acoustics, while the remainder come under the headings of optics, magnetism and electricity, argon, and miscellaneous. It is impossible in a short notice to deal adequately with the whole of the exhibits, but a few representative examples may perhaps be mentioned. The acoustics section includes apparatus used in experiments on reflection and interference and on the intensity of aerial vibrations ; also the apparatus by means of which it was demonstrated that our lateral perception of the direction of a sound depends upon the phase-difference at the two ears. One of the most important exhibits in the optical section is the apparatus used for the determination of the constant of the magnetic rotation of light in carbon disulphide, while there is also a reminder that, so early as the year 1902, Rayleigh made an attempt to detect motion through the æether. Prominent in the electrical section will be found

No. 3167, Vou. 126] 